\title{
Article
}

\section{Mental math speed test}

Davies, Janice Anne

Available at http://clok.uclan.ac.uk/38313/

Davies, Janice Anne (2021) Mental math speed test. Journal of Prescribing Practice, 3 (6). p. 222. ISSN 2631-8385

It is advisable to refer to the publisher's version if you intend to cite from the work.

10.12968/jprp.2021.3.6.222

For more information about UCLan's research in this area go to

http://www.uclan.ac.uk/researchgroups/ and search for < name of research Group>.

For information about Research generally at UCLan please go to http://www.uclan.ac.uk/research/

All outputs in CLoK are protected by Intellectual Property Rights law, including Copyright law. Copyright, IPR and Moral Rights for the works on this site are retained by the individual authors and/or other copyright owners. Terms and conditions for use of this material are defined in the policies page.

\section{CLoK}

Central Lancashire online Knowledge www.clok.uclan.ac.uk

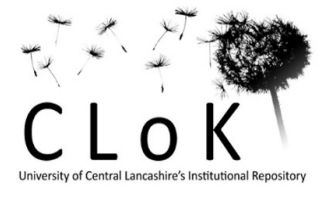




\section{Final Manuscript: Calc Skills, June.}

Mental maths is an essential skill both for the workplace and for life in general. The following questions use addition, subtraction, multiplication and division. Set a timer for 2 minutes and see how many you can complete correctly. The answers are on page 244. You could compare your score with your friends and family.

The first ten questions are a warm-up!

$71-10=61$

$10 \times 52=520$

$4 \times 70=280$

$72-32=40$

$330 / 11=30$

$59+33=92$

$32 / 8=4$

$64+8=72$

$5 \times 62=310$

$78-3=75$

Now set a 2-minute timer for these:

$79+44=123$

$36-11=25$

$7 \times 83=581$

$24-17=7$

$6 \times 17=102$

$35-23=12$

$18 \times 15=270$

$4-4=0$

$4 \times 29=116$

$10-7=3$

$9 \times 51=459$

$61+96=157$ 
$38+57=95$

$3 \times 72=216$

$5 \times 73=365$

$83+17=100$

$14-10=4$

$8 \times 20=160$

$15+75=90$

$649 / 11=59$

$6 \times 66=396$

$648 / 9=72$

$8+34=42$

$34+84=118$

$21+77=98$

$48-43=5$

$11 \times 58=638$

$35+76=111$

$96-4=92$

$2 \times 78=156$

$3+78=81$

$81-4=77$

$336 / 12=28$

$216 / 8=27$

$48-45=3$

$51+41=92$

$164 / 2=82$

$14 / 7=2$

$26+20=46$

$36-7=29$

$14+35=49$

$9 \times 63=567$ 
$21-10=11$

$64+60=124$

$66-7=59$

$680 / 8=85$

$12 \times 83=996$

$33 / 3=11$

$1116 / 12=93$

$408 / 8=51$

$440 / 11=40$

$29-16=13$

$12 \times 27=324$

$76-11=65$

$558 / 6=93$

$79+62=141$

$783 / 9=87$

$40-16=24$

$7 \times 42=294$

$6 \times 95=570$

$245 / 7=35$

$10-2=8$

$324 / 9=36$

$81 / 3=27$ 